\title{
International Cooperation in Space Activities amid Great Power Competition
}

Ludmila V. Pankova, Olga V. Gusarova, Dmitry V. Stefanovich

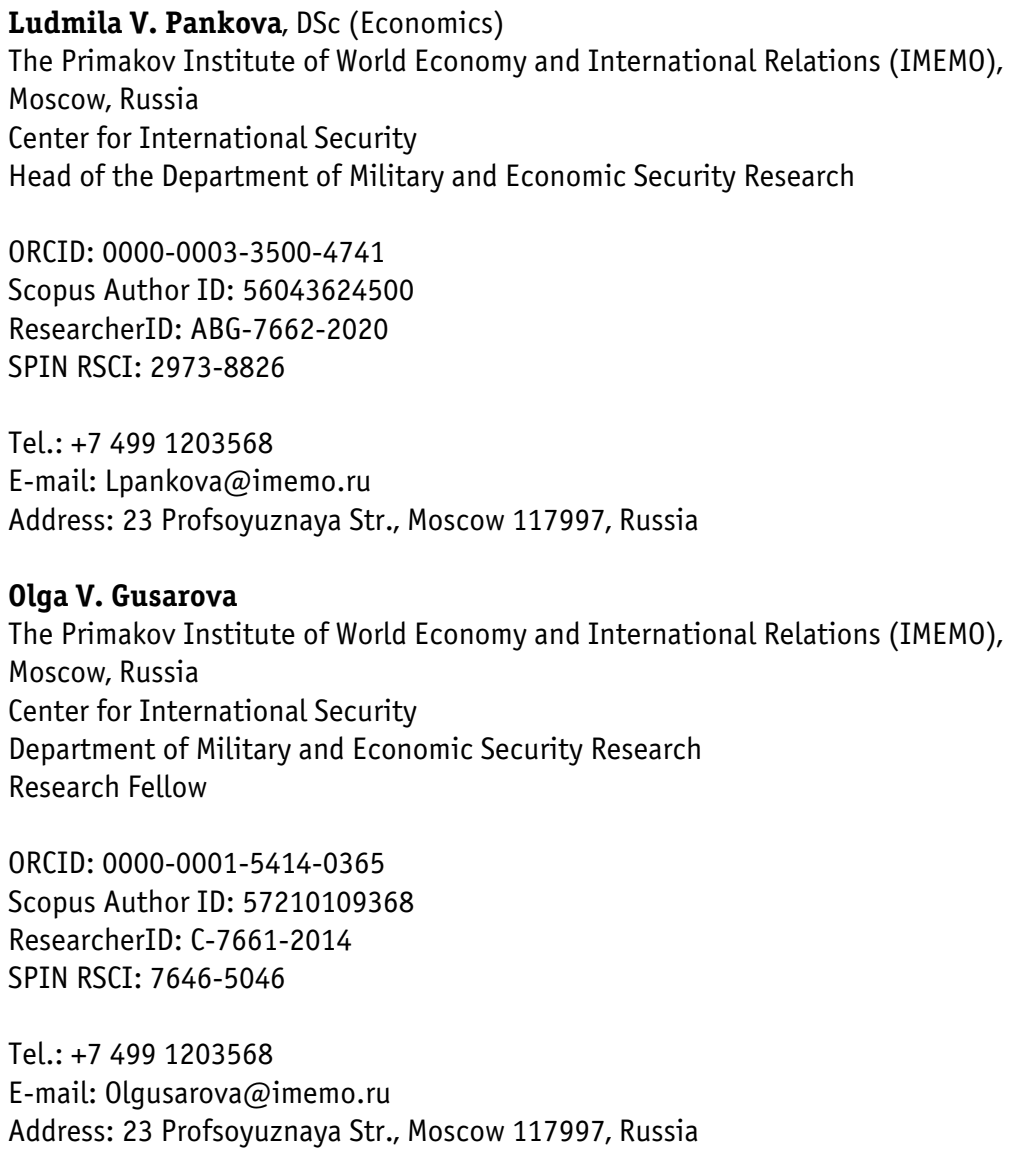




\section{Dmitry V. Stefanovich}

The Primakov Institute of World Economy and International Relations (IMEM0),

Moscow, Russia

Center for International Security

Department of Military and Economic Security Research

Research Fellow

ORCID: 0000-0002-8694-8040

Scopus Author ID: 57218529321

ResearcherID: AAN-8207-2020

SPIN-RSCI: $6548-4619$

Tel.: +7 4991203568

E-mail: Stefanovich@imemo.ru

Address: 23 Profsoyuznaya Str., Moscow 117997, Russia

This article was prepared as part of the project "The Post-Crisis World Order: Challenges and Technologies, Competition and Cooperation" supported by a grant from the Ministry of Science and Higher Education of the Russian Federation, program for research projects in priority areas of scientific and technological development (Agreement \#075-15-2020-783).

DOI: $10.31278 / 1810-6374-2021-19-4-97-117$

\section{Abstract}

In the coming decade, intensifying competition between great powers will have a significant impact on the development of space activities (SA) and on the future of international cooperation in this field. The article examines the scope, development paths and competitive advantages of individual countries in the field of space activities, and explores fundamental issues of competition and cooperation. A system analysis method is used to assess current dynamics in this area. The U.S. is expanding cooperation with its allies, while Russia is strengthening cooperation with China in the SA field. We note the "securitization" of SA development processes and emphasize the expansion of the "space" dimension of the international security agenda. There is a danger that "natural competition" may turn into "confrontation," which is a key factor influencing, inter alia, the need to change the form of organization, the principles, the strategy, and the mechanisms of international cooperation. The article also substantiates the need to strengthen the role of international cooperation in the SA field as a "binding" component of global security.

Keywords: Space, space activities, international cooperation, great-power competition, allies, commercialization, international security. 
I $n$ the 2020s, space activities (SA) are expected to undergo profound changes that will affect the scope, trajectories, and priorities of their development, and determine new opportunities and prospects. Exogenous factors will be the main sources of such changes: accelerated development of new technologies, shifts in globalization processes (a tendency towards "sovereignization" under sanctions, the possibility of radical changes in the forms of globalization, using new models and platforms of regional integration (Dynkin, 2018), etc.)), and changes in the structure of international relations.

The number of SA participants is increasing. Nine countries (U.S., Russia, China, India, Iran, Israel, Japan, DPRK, and South Korea) and one international organization (European Space Agency) have the ability to launch spacecraft (O'Callaghan, 2013). As of 2019, almost 2,000 spacecraft belonging to fifty countries, transnational organizations and corporations were already in orbit (Defense Intelligence Agency, 2019). Commercial activity in space is expanding rapidly. Small spacecraft are forming mega-constellations: in 2020, 94\% of spacecraft launched into orbit were part of such systems, but the private companies OneWeb and Starlink (a division of SpaceX) are planning to launch about 40,000 more spacecraft in the coming years (Chakrabarti, 2021).

Morgan Stanley predicts that "by 2030 the global space industry will be worth around $\$ 600$ billion" (Morgan Stanley, 2020). Some estimates indicate that it may reach $\$ 1$ trillion in ten to twenty years (Kalms et al., 2020), and will grow to $\$ 2.7$ trillion over the next thirty years (from $\$ 385.5$ billion in 2017) (Sheetz, 2017). This will be facilitated by increasing commercialization of SA. The commercial sector already makes up 75\% of the entire space industry (Di Pippo, 2019, pp. 61-63). This will also spur activity in relates areas. For example, the growth of space traffic may lead to the emergence of new markets, such as orbital congestion planning or debris removal services (Kalms et al., 2020). This will further boost technological capabilities and new scientific discoveries. But this will also require changes in legislation, policies, including their military component, strategies, and investment plans.

The new geoeconomic (including technological) and geopolitical situation increases the likelihood of conflict, as more and more 
countries use space systems for military purposes (global positioning, intelligence, surveillance, communications, missile attack warning, etc.) (SSI, 2019). It is estimated that about 150 American military and dual-purpose spacecraft, about seventy Russian and about ninety Chinese ones are currently in space. Other countries are far behind with less than ten spacecraft (UCS, 2021). As for other domains (from cyberspace (Romashkina, Markov and Stefanovich, 2020) to the Arctic (Zagorskii, 2019)), SA development processes are undergoing the socalled "securitization" (University of Bristol, 2010). Eight countries (China, Russia, U.S., France, India, Iran, Japan, and DPRK) already have anti-space capabilities (including in the field of information and communication technologies (ICT)) (Secure World Foundation, 2021), which necessitates better protection of space infrastructure. China, presumably, is somewhat ahead in terms of ground-based anti-satellite systems, while Russia (and probably the United States) surpasses it in terms of orbital anti-satellite capabilities. All three countries have welldeveloped electronic warfare and space control $\backslash$ situational awareness systems (Secure World Foundation, 2021).

With great-power competition (GPC), announced by the U.S. administration, underway (Dept of Defense, 2018, p. 2), competition in space can develop into "confrontation" and involve new participants. In order to reduce conflict potential, it is necessary to lay the foundations for expanding and strengthening international cooperation.

As a hypothesis of this study, it can be assumed that the current decade is a period of revision in all spheres of interaction between leading space powers. Positive results of such a revision will help to reduce uncertainty in the evolution of international SA; effectively link short-term policy objectives (including military ones) with longterm goals (economic, scientific, technological, and military), which, if large-scale space projects are implemented, will span decades; and determine the optimal scenario of interaction between leading space powers in outer space.

It is important to emphasize the dichotomy between competition and cooperation. Competition has advantages and disadvantages, with its determinants changing over time (Lewis, 2018). Nowadays it is not 
quantitative indicators (such as $\mathrm{R} \& \mathrm{D}$ costs, the number of scientists and engineers, etc.), but the competition of innovative ideas, investment management, and interaction in the information space that become increasingly important. Space competition has the comprehensive nature of PEMT (political, economic, military, and technological) competition (Pankova, 2021). The reason is that space activities serve a whole range of crucial national interests: political, scientific, technical, and defense. This necessitates a broad interdisciplinary approach to research, where the systemic-synergistic component plays a key role. In addition, space competition is characterized by the desire of many countries to demonstrate their independence, status, and technological capabilities (Lewis, 2014).

According to Deutsch's theory, at the core of most conflicts there is a mix of cooperative and competitive motives. A key element in understanding cooperation/competition is the type of goal interdependence found between the parties involved (this can be success/loss, loss/loss, or success/success). When stressing the importance of international cooperation in space now and in the future, NASA officials note that international cooperation can make a significant contribution to the attainment of national goals set by each partner (Younes, n.d.). Given the GPC and the commitment to domination in space, one can hardly expect the U.S. to rely on the "success/success" scenario in its interaction with Russia and China.

In our opinion, only a balance between competition and cooperation that neither slow down nor hinder each other can create necessary and sufficient conditions for the sustainable development of international space activities. While not eliminating competition completely, cooperation nevertheless significantly reduces its negative effects. Cooperation is also the most effective and rational way to reduce the risk of the destabilizing spread of space technologies, which are known to be largely dual in nature. Thus, competition and cooperation, their dichotomous linkage, are a prerequisite for progress in space activities and their sustainable development, if competition does not turn into confrontation, of course. At the same time, the risk of full-fledged confrontation in outer space is 
increasing, primarily due to the degradation of military-political relations between states down on Earth.

Unlike in the last decade of the 20th century, international space cooperation in the coming decade will not be global, but will proceed mainly between regions and blocs: on the one hand, the United States and its allies, and on the other hand, Russia and China, which do not reject cooperation with either the BRICS countries, ESA, the Middle Eastern states, or the United States itself. The expansion of U.S. space interaction with allies, the need for which was emphasized in the American Defense Space Strategy (Dept of Defense, 2020), is considered one of the United States' key asymmetric advantages visà-vis Russia and China (Rose, 2020). A departure from global space cooperation is a trend of the current decade.

\section{SA DEVELOPMENT TRAJECTORIES}

Although official U.S. documents clearly proclaim the goal of dominance in space (Dept of Defense, 2020), the U.S. nevertheless pays much attention to cooperation with its allies and partners, which will allow it to increase not only the sustainability of its space infrastructure, but also, if necessary, its operational effectiveness. According to experts, for example, the British military (Ministry of Defense, 2020), international space cooperation can take a central place in relations between the United States and its allies.

It was under the Obama administration that the National Space Policy 2010 and the National Security Space Strategy 2011 clearly proclaimed commitment to international interaction, including operational cooperation, with allies. In 2015, the U.S. military started fine-tuning the mechanism of operational interaction in space, creating the Joint Interagency Combined Space Operations Center (JICSpOC) (Dept of Defense, 2015), which was later transformed into the National Space Defense Center (NSDC). The purpose of their creation was as follows: in the face of growing threats to space capabilities, it is necessary to ensure the operational integration of the U.S. DoD and the American intelligence community, as well as civilian, commercial, allied, and partner actors, that is, to improve 
the protection and defense of critical space infrastructure amid increasing competition in outer space. By 2016, the United States had signed more than a dozen Space Situational Awareness (SSA) Sharing Agreements with foreign countries and fifty companies and commercial organizations (Moltz, 2019).

In 2018, United States and Brazil signed a similar agreement, which also provides for joint monitoring of space launches and changes in satellite orbits (Reuters, 2019a). In the fall of 2019, the Brazilian Senate approved the Technology Safeguard Agreement (TSA) with the United States, according to which American companies can launch small satellites from the Alcantara Space Center near the equator. As a result, launches will burn 30 percent less fuel and rockets can carry larger payloads (Reuters, 2019b). According to Boeing and Lockheed Martin officials (Reuters, 2019a), the signing of this agreement is extremely important for small companies such as, for example, Tucson-based Vector Launch Inc. (due to the geographical location of the launching systems).

At present, nine countries (U.S., Japan, Australia, Great Britain, the UAE, Italy, Canada, Luxembourg, and Ukraine) and ESA (European Space Agency), have signed the inter-governmental Artemis Accords laying down the principles of cooperation in civil exploration and peaceful use of the Moon, Mars, comets, and asteroids, and based on the Outer Space Treaty (Kosmolenta, 2020). According to some estimates, Artemis will become the largest and most comprehensive international manned flight program in history (Share America, 2020). The cost of the Artemis program will amount to $\$ 86$ billion by 2025 (Smith, 2021).

According to Russia, these accords, based on bilateral treaties and international agreements, are too American-centric to sign them in their present form (Russian Ministry of Foreign Affairs, 2020). The absence of China from the accords is due to the ban imposed by U.S. Congress on cooperation with it. Germany, France, and India are not yet parties to the accords either (Newman, 2020). The United States refuses to have the Artemis Accords endorsed by the UN, because in this case it will have to negotiate with Russia and China. An executive 
order signed by President Trump on April 6, 2020, which supports the commercial development of the Moon and other celestial bodies, "instructs the U.S. administration to resist any attempts to consider outer space global commons" (Interfax-Military News Agency, 2021).

The successes of the private sector (including SpaceX, Orbital ATK, Blue Origin, United Launch Alliance, Scaled Composite) are well known. The emphasis on commercial and entrepreneurial space activities and reliance on the private sector to meet public needs help to accelerate the resolution of problems, reduce risks, make projects more innovative and, possibly, less costly (Lewis, 2014, p. 8). According to some researchers, this approach is based on the U.S. government's intention to use the successful experience of the 1990s, when responsibility for the development of the Internet was transferred from the government and the military to the commercial sector, and repeat in in space activities. It is noted, however, that this will incur greater costs and risks for the private sector.

The private American companies SpaceX and Blue Origin, and the joint venture United Launch Alliance are working on parallel projects to create super heavy-lift launch vehicles for the Pentagon, each of which, according to the terms of reference, should carry military payloads at least twice as heavy as those to be lifted by Russia's newest rocket Angara A5 (Fedorov, 2020). Specific tasks for super heavy-lift launch vehicles may also include the exploration of the Moon, flights to Mars, and even the deployment of weapons in space (Lewis, 2014, p. 4). In this context, it is necessary to note that not only do technological characteristics improve, but also costs go down, which opens up "new windows of opportunity" for industry, business, and the military (Pankova and Gusarova, 2020).

Russia, for its part, has not fully made up its mind about future projects. The initial version of the "Russian Strategy for the Development of Space-Related Activities until 2030 and Beyond" named three main milestones in the development of space activities: 2015 was defined as the "restoration of possibilities"; 2020 was named as the "consolidation of possibilities"; and 2030 was determined as a "breakthrough" year (RIA Novosti, 2012). An updated version of the 
Basic Principles of State Policy in the Field of Space Activities until 2030 and Beyond was approved in 2020, but still was not published as of October 2021. Work is currently underway to draw up an action plan to achieve the specific priorities set in this document (President of Russia, 2021).

Russia is considering the possibility of building a Russian Orbital Service Station (ROSS) at a lower orbit (300-350 km (RBC, 2021)) than the International Space Station (ISS) and with a different inclination (97-98 degrees (Ivanov, 2021)), which will allow it to cover the entire territory of the country. The successful launch and docking of the multi-purpose laboratory module (MLM) to the ISS in July 2021 may extend the station's operation. Also, the MLM experience appears to be quite useful for maintaining (and restoring) skills needed for putting large spacecraft into orbit. The planned docking of the Prichal Node Module to the MLM will make it possible to test Russia's newest manned spaceship Oryol (Eagle). The Luna-25 automatic station is scheduled to be delivered to the Moon in May 2022.

As technological confrontation between the United States and China increases, Russia and China are moving towards closer cooperation with each other. A symbolic event took place on March 9, 2021, when the two countries signed a memorandum on the creation of an international scientific lunar station (MNLS) on the principles of parity rights and obligations (Roscosmos, 2021). The MNLS program is open to all interested countries and partners. Until 2025, Russia and China are planning to carry out several separate lunar missions, which should create the basis for future human flights in the next decade (Strekopytov, 2021).

Russia's competitive advantages include pilot projects in the field of compact energy sources (Suchkov and Tack, 2019), the creation of spacecraft with advanced nuclear power supply systems (Ramm, 2014, p. 9), extensive space launch capabilities, and the experience of longterm human presence in space. Of particular importance will be the completion of the work on a "nuclear-powered space tug," the Zeus transport and energy module, the first flight of which is scheduled for the next decade (TASS, 2021). This spacecraft may also be used for 
military purposes, including in the interests of air-space defense (RIA Novosti, 2021a). Russia also continues active interaction with foreign partners (especially ESA) in the field of space science.

China has exceptionally ambitious space projects at the end of the second decade of the new century. In previous decades, China was essentially cut off from international space cooperation due to U.S. sanctions. However, this did not prevent the country from making noticeable headway in space activities. By 2022, China is planning to complete the construction of the multi-module space station Tiangong, which was officially started on April 29, 2021, when the main module was successfully launched into orbit. In 2022, laboratory and research modules will be added to the station (RIA Novosti, 2021b). According to the Chinese National Space Administration (CNSA), China is planning to finish building a lunar base by the mid-2040s. In 2030, China intends to start its Miyin program to study outer space outside the solar system and search for exoplanets. There are also plans to create an Earth-Moon economic zone by 2050 (Siqi, 2019).

China's important advantages are a powerful communication infrastructure (including quantum and 5G), a large number of space startups (including space launching services), and rapid construction of full-fledged space infrastructure in general, including its own space station.

In early April 2021, the United States and Russia held consultations on space security. The Russian government approved the extension of the space cooperation agreement with the U.S. until December 31, 2030 after preliminary consultations with the Americans (Agreement, 2021). It was noted that "Russia and the United States need to develop a mechanism of cooperation in areas of overlapping interests and ways to resolve disagreements before they develop into a conflict" (Sokolsky and Rumer, 2020). Common interests in space prevail in the United States and Russia where they concern risk management during military-space activities, as well as in the field of strategic and political interests.

The range of such interests is wider between Russia and China and includes Moon and space exploration, space science and related technologies, satellites and their use, elemental base and 
materials, cooperation in the field of Earth remote sensing, etc. The two countries have stepped up consultations on the joint operation of the national navigation systems GLONASS and BeiDou and harmonization of their standards.

In terms of U.S.-China space relations, a decision adopted in 2011 prohibits NASA, which possesses critical space technologies, from contacting China in any way (Public Law 112-55, 2011). One of the reasons for this decision seems to have been the uproar surrounding China's use of American space technologies for its MIRVed ICBM program (Congressional Research Service, 2003). In the past, the United States even opposed China's participation in the ISS program. According to Yi Shen, director of Fudan University's International Research Institute of Global Cyberspace Governance (Fudan University, China), one of the key problems in AmericanChinese relations is the growing competition in the sphere of high technologies (Shen, 2020).

The American GPC concept, while raising political and militarypolitical risks of both interaction and "under-interaction," does not reject international cooperation, but complicates its principles. As the number of SA participants increases and SA commercialization progresses, space cooperation becomes inevitable. For Russia (just as for other SA participants), the main question is what place the country will occupy in the overall structure of international space interactions in the coming decades.

At the same time, the United States, China, Russia, and other space powers have common security interests. Consensus on some of them has been reached at the international level (especially on the need to address the problem of space debris). Other issues require intensive negotiation. In the short- and medium terms, this particularly applies to cyberspace security, ICT security of weapon systems, space-based early warning systems, space situational awareness systems (SSA)/space control systems (SCS).

In the long term, it could be possible to consider creating an international system to control and manage space traffic, which would help to determine and monitor threshold limits for the number of 
spacecraft in orbital constellations, since their dramatic unilateral buildup can undermine strategic stability. An international inspectorate and arbitration bodies could operate within such a system. In addition, a body tentatively called "space control agency" could provide the platform for discussing a code of conduct in outer space, including, for example, a ban on dangerous maneuvers and approaches, pursuit, a minimum distance between spacecraft, etc. (Pankova, 2019). The space agenda of international security also includes a ban on the deployment of weapons in space, including non-nuclear space-based interceptors and directed-energy weapons for anti-missile and anti-space defense, "traffic rules" for spacecraft, and the regulation of military activities in space as such.

In general, while some researchers say that a state can dominate on Earth if it has the possibility to control outer space (Dolman, 2005), others reasonably disagree with them, emphasizing that a "war in space" is nothing more than a continuation of the "war on Earth," drawing an analogy with coastal operations, rather than with the "naval strength" of ocean powers (Bowen, 2020). Indeed, confrontation in outer space cannot be considered in isolation from events on the ground. Despite a significant array of science fiction works and real space strike system projects, there has been no "role change" so far: space objects still play primarily a supporting role and serve as "targets."

\section{CRITICAL FEATURES AND TRENDS}

Current space activities have a number of distinctive features.

First, at present time, countries unite in order to complement their own capabilities, giving priority to the development of the main infrastructure "space" assets that ensure the basic independence of their space activities. The design of the infrastructure is changing: a transition from downsizing orbital constellations to building them up (a constellation of small spacecraft). As a result, cooperation steadily develops, but without deepening international specialization.

Second, most innovations today, unlike in the last decades of the 20th century, "are made in commercial organizations, not in stateowned laboratories" (Kirchhoff, 2018). 
Third, there is a shift from a technocratic model of SA development to a netocratic model whose main value is information rather than material aspects. This transition is facilitated by changes in financing patterns and activities, and by the linkage with innovative development. The "technocratic" model is characterized by national identity, a certain level of secrecy, as a rule, the leading role of the military, independence, large-sized vulnerable spacecraft, slow innovations (from top to bottom), as well as the predominance of rivalry led by the state. The "netocratic" model is characterized by more active international interactions, transparency, the leading role of the commercial sector; network structure, creation of resilient groups of small spacecraft, and rapid innovations (bottom-up) (Moltz, 2019; Grest, 2020). Prevalent is a new form of organization based on public-private and other partnerships, distributed architecture, and rapid innovations.

Fourth, the focus is mainly on Lego-style international cooperation that will be most adaptive and effective in the overall "investmentinnovation-information" network structure.

Fifth, with the GPC underway, new algorithms for the development of international space activities are being built by reformatting the system of international relations. The main factors affecting this process are the growing number of participants and the commercialization of SA. The prioritization of space confrontation as part of the GPC creates military-political risks, escalates conflicts, and fuels the struggle for space resources.

Sixth, more efforts are taken, primarily by the U.S., to increase space power. While in the 1990s, the United States used its resources mainly to achieve information superiority in space, in the first two decades of the new century it has been officially stating its intention to achieve military supremacy in space. This also includes the development of the $\mathrm{X}-37 \mathrm{~B}$ unmanned space plane, and reusable and other space carriers by private American companies (including SpaceX) to promptly restore spacecraft assets if they are lost during an armed conflict (Deifel, Somerman, Thieme, 2020) (there is no doubt that spacecraft will become just as "legitimate" a target as, for example, aircraft are). 
Particular attention should be paid to the possible "mobilization" of private space companies by the American armed forces, including in terms of influence on the entire space services market. For example, the U.S. National Reconnaissance Office (NRO) has suggested creating a Civil Reserve Space Fleet similar to existing aircraft and naval reserves (Hitchens, 2021). Interestingly, requests for proposals explicitly state the contractor's obligation not only to transfer images of the requested area of the Earth's surface to the NRO, but also to exclude their transfer to anyone else, including public domain, which is in stark contrast to the established practice of reselling the same images to different buyers, or offering access to the entire database by subscription.

The third decade of the 21 st century will lay the foundations for future international cooperation in space.

The authors of the article are confident that the world community should not lose space-it is unacceptable to politically and strategically miss the opportunity to forge global interaction in space in common interests. The fact that even today space cooperation between Russia and the United States has not been interrupted signifies that chances still remain.

In these circumstances, it would seem appropriate to:

- Identify the range of problems and objectives that require the pooling of efforts and resources and change the algorithm of cooperation from chaotic to systemic.

- Consider the interrelationship between civilian, commercial, and military programs, as well as dual-purpose programs, including with due regard to non-proliferation issues (which is important in the context of Russia's MTCR presidency in 2021-2022).

- Explore the conditions for creating network-centric space power based on the New Space concept (pooling venture capital, private enterprise, research, innovation, political and legal infrastructure to bring new space technologies into the market) (Moltz, 2019). 
- Launch a dialogue between Russia and the United States (with a view to engaging China and other countries) on potential cooperation in the military-space sphere. Particular attention should be paid to theoretical and practical research in the field of cyberspace security, taking into account not only the new technological capabilities, but also the increased vulnerability of space infrastructure. Note should also be taken of Russian officials' heightened interest in this issue (Government of Russia, 2021).

The implementation of independent but mutually coordinated space programs will determine the predominant orientation towards international Lego-style cooperation.

The United States is trying to build an American-centric system of international relations in space on the basis of bilateral cooperation. This approach is contrary to the New Space principles. At the same time, the key New Space ideas, especially the introduction of new space technologies to the market, also contradict the GPC concept.

Active international cooperation in the field of space activities (the development of a world space foresight initiative, the creation of international organizations or regimes to monitor outer space and ensure space situational awareness, etc.) should be considered not only a necessary condition for the evolution of space activities, but also an important factor in "overcoming the imbalance in international relations," and an instrument for resolving the geopolitical crisis and restoring trust between countries and regions (Pankova, 2019). International confrontation within the GPC framework creates serious obstacles on this path.

\section{References}

Agreement, 2021. Soglasheniye mezhdu Rossiyskoi Federatsiyei i Soyedinyonnymi Shtatami Ameriki o prodlenii sroka deistviya Soglasheniya mezhdu Rossiyskoi Federatsiyei i Soyedinyonnymi Shtatami Ameriki o sotrudnichestve v issledovanii $i$ ispolzovanii kosmicheskogo prostranstva $v$ mirnykh tselyakh ot 12 aprelya 2021 [Agreement between the Russian Federation and the USA on the Extension of 
the Term of the Agreement between the Russian Federation and the USA on Cooperation in the Exploration and Use of Outer Space for Peaceful Purposes, April 12, 2021]. Available at: docs.cntd.ru/document/603539821 [Accessed 8 August 2021].

Bowen, B.E., 2020. War in Space: Strategy, Spacepower, Geopolitics. Edinburgh University Press.

Chakrabarti, S., 2021. How Many Satellites Are Orbiting Earth? The Conversation [online]. Available at: theconversation.com/how-many-satellites-are-orbitingearth-166715 [Accessed 22 August 2021].

Congressional Research Service, 2003. China: Possible Missile Technology Transfers under U.S. Satellite Export Policy - Actions and Chronology. Available at: www.everycrsreport.com/reports/98-485.html [Accessed 8 August 2021].

Defense Intelligence Agency, 2019. Challenges to Security in Space [online]. Available at: media.defense.gov/2019/Feb/11/2002088710/-1/-1/1/SPACESECURITY-CHALLENGES.PDF [Accessed 30 August 2021].

Deifel, J.H., Somerman, N.M. and Thieme, M.D., 2020. Future Military Space: From Procurement to the Tactical Fight. Wild Blue Yonder, 8 June, pp. 1-53. Air University Press.

Di Pippo, S., 2019. Space Technology and the Implementation of the 2030 Agenda. UN Chronicle, 55(4). Available at: www.un.org/en/chronicle/article/ space-technology-and-implementation-2030-agenda [Accessed 30 August 2021].

Dept of Defense, 2015. New Joint Interagency Combined Space Operations Center to Be Established [online]. Available at: www.defense.gov/Newsroom/Releases/ Release/Article/616969/new-joint-interagency-combined-space-operationscenter-to-be-established/ [Accessed 30 August 2021].

Dept of Defense, 2018. Summary of the 2018 National Defense Strategy of The United States of America. Sharpening the American Military's Competitive Edge [online]. Available at: dod.defense.gov/Portals/1/Documents/pubs/2018National-Defense-Strategy-Summary.pdf [Accessed 19 October 2021].

Dept of Defense, 2020. Defense Space Strategy: Summary [online]. Available at: media.defense.gov/2020/Jun/17/2002317391/-1/-1/1/2020_DEFENSE_SPACE_ STRATEGY_SUMMARY.PDF [Accessed 30 August 2021].

Dolman, E.C., 2005. Astropolitik: Classical Geopolitics in the Space Age. Routledge. 
Dynkin, A.A., 2018. Foreword. In: A. Dynkin (ed.) The World of 2035. Global Outlook. Moscow: Magistr.

Fedorov, D., 2020. Novy zakon Trampa vozvedyot zvezdnye voiny k statusu realnosti [Trump's New Law Will Bring Star Wars to Reality]. News Front [online]. Available at: news-front.info/2020/01/16/novyj-zakon-trampavozvedyot-zvyozdnye-vojny-k-statusu-realnosti/ [Accessed 31 August 2021].

Government of Russia, 2021. Video Message from Mikhail Mishustin to the Participants of the International Online Training on Cybersecurity Cyber Polygon. Available at: government.ru/news/42723/ [Accessed 31 August 2021].

Grest, H., 2020. New Space. Advantage or Threat for the Military? In: Transforming Joint Air \& Space Power: The Journal of the JAPCC, 29, pp. 31-36. Joint Air Power Competence Centre.

Hitchens, T., 2021. NRO Space 'Civil Reserve' Includes Shutter Control Option. Breaking Defense, 30 July [online]. Available at: breakingdefense.com/2021/07/ exclusive-nro-space-civil-reserve-includes-shutter-control-option/ [Accessed 8 August 2021].

Interfax-Military News Agency, 2021. Rogozin ne zhdyot uluchsheniya otnosheniy RF-SShA v sfere kosmosa [Rogozin Does Not Expect an Improvement in Russia-U.S. Relations in the Space Field]. Military News [online]. Available at: www.militarynews.ru/story.asp? $r i d=1 \&$ nid=544556\&utm_ source=yxnews\&utm_medium=desktop\&utm_referrer=https://yandex.ua/news/ story/Rogozin_ne_zhdet_uluchsheniya_otnoshenij_RF-SSHA_vsfere_kosmosa-c3348f232c944d00c07f77e3d4f5d085\&lang=RU [Accessed 31 August 2021].

Ivanov, O., 2021. Istinny ROSS. Rossiya sozdayot svoyu kosmicheskuyu stantsiyu. Chto o nei izvestno? [Genuine ROSS. Russia Is Building Its Own Space Station. What Is Known about It?]. Lenta.ru [online]. Available at: lenta. ru/articles/2021/06/01/ross/ [Accessed 31 August 2021].

Kalms, M., Hacker, J., Mabbott, J. and Lanfranconi S., 2020. 30 Voices on 2030: The Future of Space. KPMG [online]. Available at: assets.kpmg/content/dam/kpmg/ $\mathrm{au} / \mathrm{pdf} / 2020 / 30$-voices-on-2030-future-of-space.pdf [Accessed 30 August 2021].

Kirchhoff, C., 2018. Why Silicon Valley Must Go to War. Nytimes.com [online]. Available at: www.nytimes.com/2018/05/02/opinion/silicon-valley-pentagon. html [Accessed 23 August 2021].

Kosmolenta, 2020. Yeshcho neskolko slov ob Artemis Accords [A Few More Words about Artemis Accords]. Kosmolenta [online]. Available at: kosmolenta. com/index.php/1592-2020-05-17-accords [Accessed 31 August 2021]. 
Lewis, J., 2014. Space Exploration in a Changing International Environment. A Report of the CSIS Strategic Technologies Program. Center for Strategic and International Studies (CSIS) [online]. Available at: csis-website-prod. s3.amazonaws.com/s3fs-public/legacy_files/files/publication/140708_Lewis_ SpaceExploration_Web.pdf [Accessed 31 August 2021].

Lewis, J., 2018. Technological Competition and China. CSIS [online]. Available at: www.csis.org/analysis/technological-competition-and-china [Accessed 30 August 2021].

Ministry of Defence, 2020. Towards a Defence Space Strategy [online]. Available at: assets.publishing.service.gov.uk/government/uploads/system/uploads/ attachment_data/file/712376/MOD_Pocket_Tri-Fold_-_Defence_Space_ Strategy_Headlines.pdf [Accessed 30 August 2021].

Moltz, J.C., 2019. The Changing Dynamics of Twenty-First-Century Space Power. Journal of Strategic Security, 12(1), pp.15-43.

Morgan Stanley, 2020. Space: Investing in the Final Frontier. Morgan Stanley [online]. Available at: www.morganstanley.com/ideas/investing-in-space [Accessed 17 October 2021].

Newman, C., 2020. Artemis Accords: Why Many Countries Are Refusing to Sign Moon Exploration Agreement. The Conversation [online]. Available at: theconversation.com/artemis-accords-why-many-countries-are-refusing-tosign-moon-exploration-agreement-148134 [Accessed 31 August 2021].

O'Callaghan, J., 2013. How Many Countries Have Rockets Capable of Reaching Space? All About Space Magazine. Spaceanswers.com [online]. Available at: www.spaceanswers.com/space-exploration/how-many-countries-have-rocketscapable-of-reaching-space/ [Accessed 30 August 2021].

Pankova, L.V., 2019, November. Worldwide Space Activity: Necessity of Strategic Foresight. In: AIP Conference Proceedings, Vol. 2171, No. 1. AIP Publishing LLC.

Pankova, L.V., 2021, February. Competition in Space: Opportunities, Consequences and Risks to International Security. In: AIP Conference Proceedings, Vol. 2318, No. 1, p. 070020. AIP Publishing LLC. doi. org/10.1063/5.0035827

Pankova, L. and Gusarova, O., 2020. Nauchno-tekhnologicheskaya proektsiya kosmicheskoi deyatelnosti [Scientific and Technological Projection of Space Activities]. In: A. Arbatov (ed.) Kontrol nad vooruzheniyami v novykh voennopoliticheskikh i tekhnologicheskikh usloviyakh [Arms Control in the New Military-Political and Technological Conditions]. [online]. Moscow: IMEMO, 
pp.88-104. Available at: www.imemo.ru/files/File/ru/publ/2020/2020-04.pdf [Accessed 31 August 2021].

President of Russia, 2021. Meeting on Long-Term Priorities of Space Exploration [online]. Available at: en.kremlin.ru/events/president/news/65348 [Accessed 1 September 2021].

Public Law 112-55, 2011. Consolidated and Further Continuing Appropriations Act, 2012, 112th Congress, U.S.

Ramm, A., 2014. Rostki shestogo uklada [The Seedlings of the Sixth Technological Setup]. Voenno-promyshlenny kuryer [online]. Available at: vpknews.ru/sites/default/files/pdf/VPK_43_561.pdf [Accessed 1 September 2021].

RBC, 2021. Roskosmos pokazal pervy modul rossiyskoi orbitalnoi stantsii [Roscosmos Showed the First Module of the Russian Space Station]. RBC [online]. Available at: www.rbc.ru/technology_and_media/23/04/2021/6082b 5ed9a7947102e3faf83 [Accessed 31 August 2021].

Reuters, 2019a. Brazil to Sign Accord with U.S. on Space Technology Next Week. Reuters [online]. Available at: www.reuters.com/article/us-space-brazil-usaidUSKBN1QS2T2 [Accessed 30 August 2021].

Reuters, 2019b. Brazil Senate Approves Technology Safeguard Agreement with U.S. Reuters [online]. Available at: www.reuters.com/article/us-brazil-politicsspace-idUSKBN1XM2YN [Accessed 30 August 2021].

RIA Novosti, 2012. Rossiya do 2030 goda dolzhna preodolet' tri "kosmicheskikh" rubezha [By 2030 Russia Is to Overcome Three "Space Frontiers"]. RIA Novosti [online]. Available at: ria.ru/20120427/63645668.html [Accessed 1 September 2021].

RIA Novosti, 2021a. Kosmichesky buksir “Zevs” smozhet vyvodit' iz stroya sputniki protivnika [Zeus Space Tug Will Be Able to Disable Enemy Satellites]. RIA Novosti [online]. Available at: ria.ru/20210709/zevs-1740535623.html [Accessed 8 August 2021].

RIA Novosti, 2021b. Kitai zapustil k svoei stantsii korabl s tremya kosmonavtami [China Launches Spacecraft with Three Astronauts to Its National Space Station]. RIA Novosti [online]. Available at: ria.ru/20211015/kitay-1754808172. html [Accessed 18 October 2021].

Romashkina, N., Markov, A. and Stefanovich, D., 2020. Mezhdunarodnaya bezopasnost', strategicheskaia stabilnost' i informatsionnye tekhnologii [International Security, Strategic Stability and Information Technologies]. Moscow: IMEMO. 
Roscosmos, 2021. Heads of Roscosmos and CNSA Discussed International Lunar Research Station Creation. Roscosmos [online]. Available at: en.roscosmos. ru/22016/ [Accessed 8 August 2021]

Rose, F., 2020. The U.S. Defense Space Strategy Works on Paper, But Will It Be Implemented? Brookings [online]. Available at: www.brookings.edu/blog/orderfrom-chaos/2020/07/06/the-u-s-defense-space-strategy-works-on-paper-butwill-it-be-implemented/ [Accessed 31 August 2021].

Russian Ministry of Foreign Affairs, 2020. Kommentarii Departamenta informatsii i pechati MID Rossii $k$ voprosu issledovaniya, osvoeniya i ispolzovaniya kosmicheskikh resursov [Commentary by the Information and Press Department of the Russian Foreign Ministry on the Exploration, Development and Use of Space Resources] [online]. Available at: www.mid.ru/foreign_policy/news/-/ asset_publisher/cKNonkJE02Bw/content/id/4392579 [Accessed 31 August 2021].

Secure World Foundation, 2021. Global Counterspace Capabilities. Secure World Foundation [online]. Available at: swfound.org/media/207162/swf_global_ counterspace_capabilities_2021.pdf [Accessed 31 August 2021].

Share America. 2020. U.S. Allies Pledge to Cooperate in Space Exploration [online]. Available at: share.america.gov/u-s-allies-pledge-to-cooperate-inspace-exploration/ [Accessed 31 August 2021].

Sheetz, M., 2017. The Space Industry Will Be Worth Nearly $\$ 3$ Trillion in 30 Years, Bank of America Predicts. CNBC [online]. Available at: www.cnbc. com/2017/10/31/the-space-industry-will-be-worth-nearly-3-trillion-in-30years-bank-of-america-predicts. html [Accessed 30 August 2021].

Shen, Yi, 2020. Security and Interdependence: How to Avoid Negative Spillover Effect of Sino-U.S. Tech Competition. Valdai Discussion Club [online]. Available at: valdaiclub.com/a/highlights/security-and-interdependence/ [Accessed 8 August 2021].

Siqi, C., 2019. China Mulls $\$ 10$ Trillion Earth-Moon Economic Zone. Global Times [online]. Available at: www.globaltimes,cn/content/1168698.shtml, [Accessed 8 August 2021].

Smith, M., 2021. NASA IG: Artemis Will Cost $\$ 86$ Billion Through FY2025, Launch Dates "Highly Unlikely". Spacepolicyonline.com [online]. Available at: spacepolicyonline.com/news/nasa-ig-artemis-will-cost-86-billion-throughfy2025-launch-dates-highly-unlikely/ [Accessed 31 August 2021].

Sokolsky, R. and Rumer, E., 2020. U.S.-Russian relations in 2030. Carnegie Endowment for International Peace. Available at: carnegieendowment. 
org/2020/06/15/u.s.-russian-relations-in-2030-pub-82056 [Accessed 8 August 2021].

SSI, 2019. Space Security Index 2019. Executive Summary [online]. Available at: spacesecurityindex.org/wp-content/uploads/2019/10/SSI2019ExecutiveSumma ryCompressed.pdf [Accessed 8 August 2021].

Strekopytov, V., 2021. Otnosheniya kosmicheskogo masshtaba: Rossiya i Kitai postroyat bazu na Lune [Space-Scale Relations: Russia and China To Build a Base on the Moon]. RIA Novosti [online]. Available at: ria.ru/20210322/luna160238321.html [Accessed 31 August 2021].

Suchkov, M. and Tack, S., 2019. Budushchee voiny [The Future of War], Valdai Discussion Club [online]. Available at: valdaiclub.com/files/26032/ [Accessed 8 August 2021].

TASS, 2021. Pervaya missiya rossiyskogo yadernogo buksira "Zevs" zaimyot 50 mesyatsev [The First Mission of the Russian Nuclear Tug Zeus Will Take 50 Months]. TASS [online]. Available at: tass.ru/kosmos/11446501 [Accessed 8 August 2021].

UCS, 2021. UCS Satellite Database. Union of Concerned Scientists [online]. Available at: www.ucsusa.org/resources/satellite-database [Accessed 22 August 2021].

University of Bristol, 2010. The Securitization of Outer Space: Challenges for Arms Control. Working Paper, No. 10(2) [online]. Available at: www.bristol. ac.uk/media-library/sites/spais/migrated/documents/peoples0210i.pdf [Accessed 19 October 2021].

Younes, B., n.d. International Cooperation in Space: Now More Than Ever. NASA [online]. Available at: www.nasa.gov/sites/default/files/696854main Pres_International_Cooperation_in_Space.pdf [Accessed 31 August 2021].

Zagorsky, A., 2019. Bezopasnost'v Arktike [Security in the Arctic]. Moscow: IMEMO. 